Jurnal Ilmial

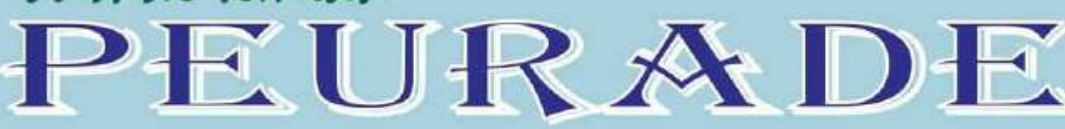

Vol. 5, No. 1, January 2017

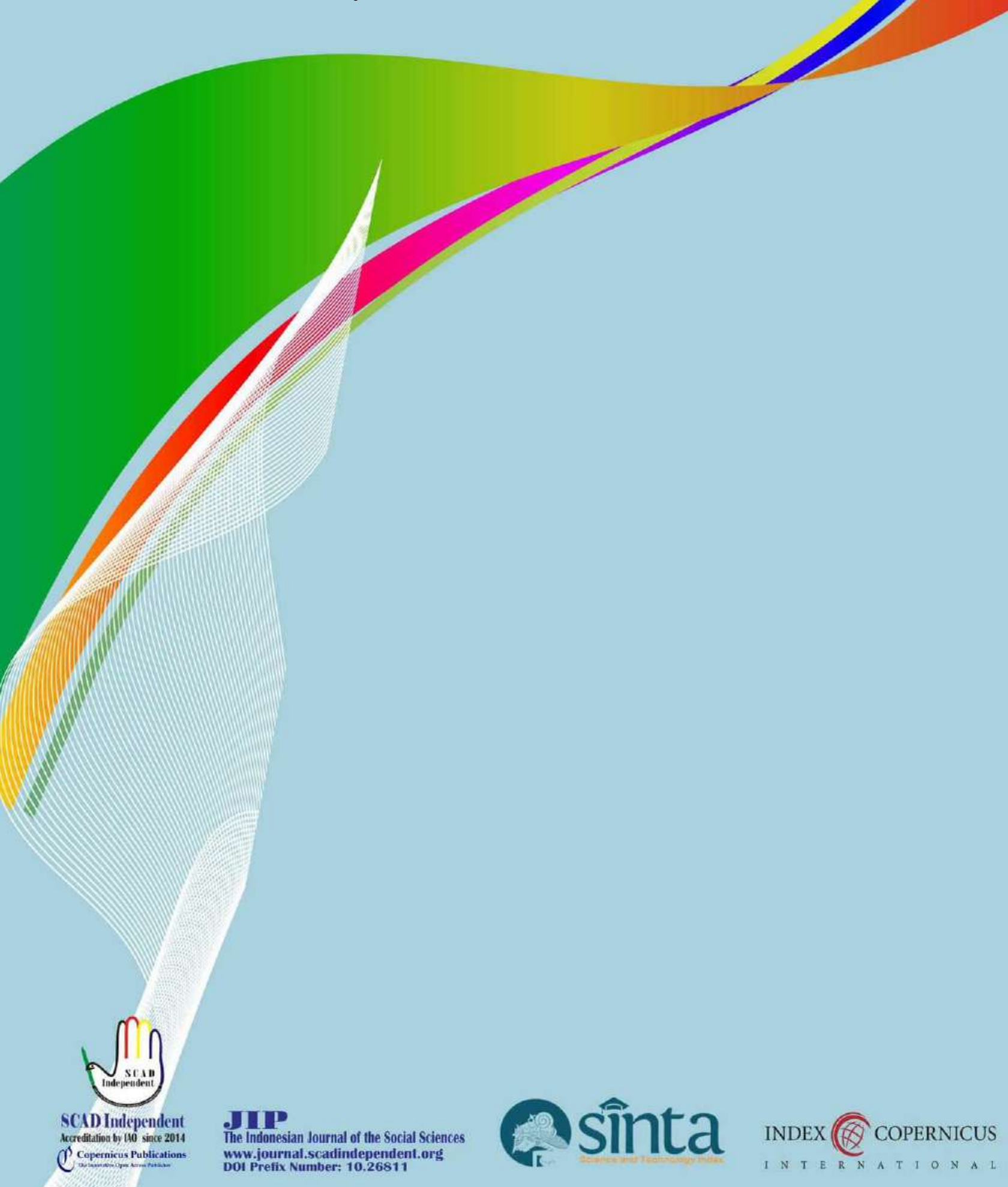




\title{
DIFFERENCE CULTURAL STRUCTURE AND BEHAVIOR STUDENTS IN LEARNING PROCESS
}

\author{
Claudia Pamela ${ }^{1}$; Luciana Villalobos ${ }^{2}$ Nadine Peralta ${ }^{3}$ \\ Universidad de Lima, Santiago de Surco Lima, Peru \\ ${ }^{1}$ Contibutor Email: claudiapamela73@gmail.com
}

Received: Jun 18, 2016

Accepted: Jul 25, 2016

Published: Jan 28, 2017

Article Url: http://journal.scadindependent.org/index.php/jipeuradeun/article/view/115

\begin{abstract}
This paper summarizes some observations and reflections on how cultural differences bedeviled my interactions with my students in Universidad de Lima, Peru. Culture is not an abstract force that floats around in space and settles upon us - though given the seemingly subliminal ways it influences us, it can feel like a disembodied, ubiquitous entity. In fact, culture is mediated through a social structure. In general, culture refers to the ways in which different groups of people organize their daily lives within national or ethnic groups, urban neighborhoods, companies and professions, and other settings. Culture includes what people actually do and what they believe. Culture influences greatly how we see the world, how we try to understand it and how we communicate with each other. Therefore, culture determines, to a great extent, learning and teaching styles. When we compare cultures we should not look for differences that make us better or worse than each other. No culture is better than another and no communication style is intrinsically wrong. My teaching and communication styles are deeply rooted in the way I have been socialized and a year of teaching at college reminded me that my students' communication and learning styles were different from mine. Perhaps the most important lesson I learned is that I must adapt to this new environment and change the way I communicate if I wish to be an effective teacher.
\end{abstract}

Keywords: Culture Influences, Classroom, Teacher, Learning Process, College 


\section{A. Introduction}

In the academic social sciences, students are taught to think of culture as representing the customs and mores of a society, including its language, art, laws, and religion. Such a definition has a nice neutral sound to it, but culture is anything but neutral. Much of what is thought to be our common culture is the selective transmission of class-dominated values. Antonio Gramsci (1971: 238) understood this when he spoke of class hegemony, noting that the state is only the "outer ditch behind which there [stands] a powerful system of fortresses and earthworks," a network of cultural values and institutions not normally thought of as political.

This paper summarizes some observations and reflections on how cultural differences bedeviled my interactions with my students in Universidad de Lima, Peru.

Culture is not an abstract force that floats around in space and settles upon us-though given the seemingly subliminal ways it influences us, it can feel like a disembodied, ubiquitous entity. In fact, culture is mediated through a social structure. We get our culture from a network of social relations involving other people: primary groups such as family, peers, and other informal associations within the community or, as is increasingly the case, from more formally articulated and legally chartered institutions such as schools, media, churches, government agencies, corporations, and the military (Large, 1980: 35).

In general, culture refers to the ways in which different groups of people organize their daily lives within national or ethnic groups, urban neighborhoods, companies and professions, and other settings. Culture includes what people actually do and what they believe. Culture influences greatly how we see the world, how we try to understand it and how we communicate with each other. Therefore, culture determines, to a great extent, learning and teaching styles.

Addressing cultural differences in the teaching-learning process is both important and controversial. It is important because we are confronted with an increasingly diverse population of students and the wide achievement gap between minority and non-minority students. It is controversial because we 
may fall into the trap of cultural stereotyping and making naive attempts to explain achievement differences among our students.

Teachers cannot escape the fact that their communication "styles" reflect their cultural background. Much of what they say, the way they say it, and their relationship with students, parents and colleagues are deeply influenced by the way they have been socialized. As a recent migrant to the United States from Costa Rica, this fact became abundantly clear to me. I came with 12 years of teaching experience and a solid knowledge of science. I felt confident and prepared for my first teaching job. This job, however, proved to be puzzling and difficult. Besides issues of classroom management, loads of paper work, school administration and general expectations, the single most important challenge I faced was coping with the enormous culture shock I experience in the classroom.

\section{B. Method}

The method used in this research is to use entries from my personal diary, conversations with colleagues and friends, evaluations of my administrators, and copies of my disciplinary referrals of students to the principal's office to identify the major conflictive moments of this year. For most of these moments, I analyzed whether they were partially or completely based on cultural differences between my students and me. I also interpreted the results of the Questionnaire on Teacher Interaction relevant to whether differences in communication styles were partly responsible for continual conflicts between my students and me.

\section{Research Finding}

The major sources of cultural conflict I identified in my interaction with my students can be separated into two categories. One relates to the development of scientific concepts and to ways in which we see the world and try to understand it. I called these "conceptual conflicts". The other category I called "behavioral conflicts". These conflicts were related to interpersonal interactions and had to do with general expectations, attitudes and behaviors. 


\section{Discussion}

1. Conceptual Conflicts

Conceptual conflicts with my college students arose mainly because I approached teaching science by facilitating learning based on cognitive patterns and generalities. I tried teaching science and the world around us more by looking at and explaining patterns than by concentrating on the details. I had never experienced difficulties with this approach when teaching in my country. I found that the majority of my students in college preferred to "see the trees before they saw the forest." They were more comfortable understanding components, facts and specifics of an idea than thinking and talking about general concepts. I lost them easily because they got impatient and wanted "the bottom line." They complained that I talked "too big." I discovered the majority of my students learned through linear logic and I had to adapt my teaching style accordingly.

Another source of conceptual conflict arose from the fact that students demanded an immediate and concrete utility to the material presented to them. They got impatient about wanting to see immediately "the point" to what I was presenting. This conflicted with the teaching style I was accustomed to using. Students in Costa Rica trust that the material taught at school is something you are supposed to know. They do not question its immediate utility and they are much more willing to go along with a teacher's lesson plan. My college students lost interest in the subject very quickly and were not willing to explore an idea beyond its immediate or possible utility.

I believe that the cultural conflict I felt was partly due to the fact that most American students view school principally as a means to getting a job and making money. School in my country is not only about preparing for the job market but also about learning things you did not know before; therefore, no matter how impractical a topic may look, Costa Rican students try to learn about it when presented by the teacher. This difference in expectations on the part of my college students caused frequent class disruption. They refused to discuss a topic if they saw no practical utility to it or interrupted 
lectures to ask why they had to learn about a particular subject. Such conceptual demands generated great frustration for me, and a general feeling of miscommunication and misunderstanding in the classroom.

2. Behavioral conflicts.

The main source of behavioral conflicts was that students interpreted my soft speech and calm disposition as a sign of weakness and tried to step over me all the time. They were very loud and disrespectful at the beginning of the school year, did not pay attention, nor tried to understand and follow directions. They very clearly needed to hear a stronger voice and expected me to identify misbehaving students publicly. As the school year progressed, I had to raise my voice and become more forceful, a communication strategy with which I was very uncomfortable.

In the schools I had attended and taught in Costa Rica, respect for the teacher is a given. The teacher is the authority figure. In College, I spent a great deal of effort and class time trying to maintain control of my students. By the end of the school year, I perceived that my students had a very ambivalent feeling regarding classroom power structure. I felt that my students needed and wanted a very strong teacher figure, but at the same time they resented the power of a teacher and needed to feel they were in control.

My students sent a loud and clear message that they wanted more freedom in the classroom. But I did not find them willing and able to take responsibility for their own learning and they very seldom showed me they would use their time and resources wisely. They needed constant, direct, clear and very specific directions in order to complete any assigned task. They wanted to get from me the specific answers to the exercises presented to them and they felt very uncomfortable when I told them that several different answers would work. I found myself spoon-feeding them more times than I felt was reasonable.

This need for constant supervision was new to me. Eighth graders in Costa Rica are already in a high school setting and do not expect so much individual attention. My College students, on the other hand, 
demanded lots of individual attention. Many times they screamed for it! This constant need for attention and the way in which it was demanded resulted in many class management problems. Students wanted me to attend to them constantly and simultaneously. They also wanted to have instructions repeated individually and then given the answers to the written exercises quickly. Few felt challenged to try to figure out a problem on their own before calling me. Many chose to misbehave to get my immediate attention. For example, if I did not attend to a student immediately after he/she had called me, she/he began playing, walking around the classroom, or calling me loudly and repeatedly.

Practice and repetition are important aspects of the learning process in the Costa Rican school system. It is how students master a new skill. Conflicting moments arose in my College classes when students refused to complete exercises because they felt they were too many or because they did not see the point in doing more if they got the first ones right. My insistence on having the students do multiple examples produced negative reactions that frustrated me and created an uneasy atmosphere in the classroom. For example, sometimes students began screaming, "This is boring" or "This is stupid" or "What is the point?" interrupting students that were working and inducing others to quit doing the exercises. Students would also yell, "This is boring" anytime an assignment was difficult, long, or self-directed.

As a general rule, students may be more inclined to learn when engaged in fun activities. But students in many countries do not expect to have fun every day and every minute in the classroom. They would not refuse to complete a task just because they do not find it entertaining. I was very puzzled and frustrated by the complaints of my College students that we did "too much work". Any difficult or challenging task was not fun and therefore was not worth doing!

Another area of cultural conflict was my students' need for individual recognition, constant praise, and instant material rewards. This need for instant gratification was alien and surprising to me. For example, at the beginning of the school year I almost had a revolt in one of 
my classes because I did not give students a pizza party the day after I returned from a leave of absence. They said they were very good with the substitute teacher and demanded a pizza party. When I said I was glad they were good since I expected them to do just that, and that a pizza party was not necessary, they felt I was being unfair to them and began screaming at me.

They also complained that I did not give them candy when they behaved well. I realized that I had to adapt my style to meet the needs and expectations of the students, and as the year progressed I began giving treats to my students. However, I believe they remained with the feeling of not being rewarded in my classes and I never felt comfortable with the idea of providing rewards for everyday tasks that they were expected to complete. Not being aware of these student expectations created many behavioral conflicts and increased my frustration.

\section{Communication in Classroom}

A 64-item Questionnaire on Teacher Interaction was applied to two of my classes: one class of Spanish immersion students and another of regular Physical Science students. This questionnaire is designed to measure classroom interaction. The results describe how a teacher interacts with her/his students and basically maps teacher behavior.

Before applying the questionnaire, I hypothesized that I was communicating more effectively with the immersion students because (a) I was teaching them in my native language and (b) I was developing my own curriculum and materials for the class. Interestingly, there was little discrepancy in the way my two classes perceived me as a teacher. The figures obtained in both classes were almost identical. Teaching in Spanish did not give me any particular advantage when communicating with my immersion students. Although I thought my lessons were more effective with these students, they saw me in a very similar way as the students I instructed in English. In general, communication was not felt to be antagonistic and the students did not have as bad an image of me as I thought they did by the way they behaved in class. 
When comparing my results with the students' opinions, I found that the students and I agreed on the areas where most of the communication was taking place but disagreed on the intensity of the interactions. I thought I was being more assertive and stricter than the way the students felt I was. A very positive result was that despite all the frustration I was feeling at that point, my communication with the students was taking place in a general framework of cooperation.

Also noteworthy was a major discrepancy shown in the results of the Questionnaire concerning the perception that I had of myself as a teacher halfway through the year compared to the one that I had before I began my year at College. I began this year feeling I was a tough, yet amicable and organized teacher. Halfway into the year I was seeing myself much more softened (more willing to give breaks) and helpful than I used to be. My teaching and communication styles were not working at College and I had to adapt quickly, but such adaptation brought feelings of uneasiness on my part that remained throughout the year.

\section{E. Conclusion}

Culture is not an abstract force that floats around in space and settles upon us - though given the seemingly subliminal ways it influences us, it can feel like a disembodied, ubiquitous entity. In fact, culture is mediated through a social structure. In general, culture refers to the ways in which different groups of people organize their daily lives within national or ethnic groups, urban neighborhoods, companies and professions, and other settings. Culture includes what people actually do and what they believe. Culture influences greatly how we see the world, how we try to understand it and how we communicate with each other. Therefore, culture determines, to a great extent, learning and teaching styles. My personal experience as a first year teacher at Universidad de Lima, Peru, has led me to recognize the important role culture plays in the teaching-learning process. I was able to identify conceptual and behavioral differences between my students and me in teaching and learning science that I believe were culturally based. Some of the differences impacted negatively on general class management. 
I believe I was not the only one that was experiencing culture shock. My students' perceptions and awareness of cultural differences were strong and permeated the classroom. I also felt many times that my expectations and demeanor were out of sync with the cultural environment at college. In addition, I found it interesting that students and teachers at this middle school live in a culturally diverse environment without being fully aware of what makes us different and how we can transcend these differences to communicate better with each other.

When we compare cultures we should not look for differences that make us better or worse than each other. No culture is better than another and no communication style is intrinsically wrong. My teaching and communication styles are deeply rooted in the way I have been socialized and a year of teaching at college reminded me that my students' communication and learning styles were different from mine. Perhaps the most important lesson I learned is that I must adapt to this new environment and change the way I communicate if I wish to be an effective teacher. In the future, I hope I will be able to create classrooms where different cultures converge and where individuals are willing to reach out and meet on the common ground that we all share as human beings.

\section{Bibliography}

Altanchimeg, Z., Battuya, D., \& Tungalag, J. (2016). The Current Circumstances and Challenges of Migrant Labor Force of Mongolia in North Eastern Asia. Jurnal Ilmiah Peuradeun, 4(1), 27-38.

Bakar, A., \& Anwar, A. (2015). Learning Materials in Character Education. Jurnal Ilmiah Peuradeun, 3(3), 405-416.

Dunn, R. et al. (1990). Cross-cultural differences in learning styles of elementary-age students from four ethnic backgrounds. Journal of Multicultural Counseling and Development, 18(2).

Gramsci, Antonio. (1971), Selections from the Prison Notebooks, New York: International Publishers.

Gudykunst, W.B. et al. (eds). (1996). Communication in personal relationships across cultures. SAGE Publications: Thousand Oaks, CA. 
Guild, P. (1994). The culture/ learning style connection. Educational Leadership, 51(8).

Janzen. R. (1994). Melting pot or mosaic? Educational Leadership, 51(8).

Kaylene, P., \& Rosone, T. L. (2016). Multicultural Perspective on the Motivation of Students in Teaching Physical Education. Jurnal Ilmiah Peuradeun, 4(1), 115-126.

La Torre, C. G., \& Montalto, K. F. (2016). Transmigration, Multiculturalism and Its Relationship to Cultural Diversity in Europe. Jurnal Ilmiah Peuradeun, 4(1), 39-52.

Lampe, P.E. (1988). The problematic nature of interracial and interethnic communication. The Social Studies, 79(3).

Large, Martin. (1980). Who's Bringing Them Up? (Gloucester, England: M.H.C. Large.

Lawton, M. (1993). Differing on diversity. Education Week, 13(13).

Manning, M.L. \& R. Lucking. (1993). Cooperative learning in multicultural classrooms. The Clearing House, 67(1).

Samovar, L.A \& R.E. Porter. (1997). Intercultural Communication -A Reader. $8^{\text {th }}$ Edition. Wadsworth Publishing Co.

Samovar, L.A. et al. (1998). Communication between cultures. $3^{\text {rd }}$ Edition. Wadsworth Publishing Co.

Sulaiman, S. (2015). Classroom Management and the Implications to Quality of Learning. Jurnal Ilmiah Peuradeun, 3(3), 431-440.

Tabrani. ZA. (2014). Islamic Studies dalam Pendekatan Multidisipliner (Suatu Kajian Gradual Menuju Paradigma Global). Jurnal Ilmiah Peuradeun, 2(2), 127-144.

Tabrani. ZA. (2014). Isu-Isu Kritis dalam Pendidikan Islam. Jurnal Ilmiah Islam Futura, 13(2), 250-270

Trachtenberg, S.J. (1990). Multiculturalism can be taught only by multicultural people. PHI DELTA KAPPAN, 71 (8).

Wilson, A. (1982). Cross-cultural experiential learning for teachers. Theory into Practice, 21(3).

Yusoff, M. Z. M., \& Hamzah, A. (2015). Direction of Moral Education Teacher To Enrich Character Education. Jurnal Ilmiah Peuradeun, 3(1), 119-132. 